\title{
Flow Characteristic Variations on Groyne Types for Aquatic Habitats
}

\author{
Joongu Kang, Hongkoo Yeo, Sanghwa Jung \\ Department of Water Resource Research, Korea Institute of Construction Technology, Ilsan, Korea \\ Email: jgkang02@kict.re.kr, yeo917@kict.re.kr, kikimorah@kict.re.kr
}

Received August 11, 2012; revised September 10, 2012; accepted September 19, 2012

\begin{abstract}
The field formed by groyne has the function of aquatic habitats for the underwater biology. The characteristic of groyne field occurring around downstream of groyne depends on groyne type and shape. Thus to maximize the function of groyne, it needs to understand the flow characteristic around groyne. In this study, experiment model test was conducted in recirculation zone located in downstream of groyne. Groyne types for experiment are three: permeable, impermeable and inclined crest groyne. LSPIV (Large Scale Particle Image Velocimetry) is used to measure flow field around the groyne and it revealed flow characteristic in recirculation zone at each case. In order to estimate the aquatic habitats of groyne fields, critical swimming speed of major fleshwater fish in Korea was compared with the variation of velocity distribution in groyne fields. From the results, the rate of velocity decreases in groyne fields, $\mathrm{V} / \mathrm{V}_{\text {app }}$ were measured to be 0 to 0.5 and the results can be fundamental data which are used to estimate the aquatic habitable function of groyne.
\end{abstract}

Keywords: Groyne; Recirculation Area; Aquatic Habitats; Critical Swimming Speed

\section{Introduction}

Groyne is the structure that is constructed in bank or foresight of riverside and has the function such as bank protection, flow control and water depth control of main stream. Recently, the installation purpose of groyne is spread to habitable place for underwater biology and fishes as raising a role of environmental function in recirculation zone. Flow around groyne is divided into two fields; Groyne field occurring recirculation zone by flow separation and main field occurring flow change by protrusion of groyne. Flow velocity in recirculation zone is low and various comparing to main stream so that recirculation zone can be used to aquatic habitats. The recirculation zone can be defined as recirculation length, $\mathrm{S}_{\mathrm{L}}$ and width, $S_{h} . S_{L}$ means the maximum downstream length from installation point of groyne and $S_{h}$ is maximum width. Thus size of recirculation zone can be defined through $\mathrm{S}_{\mathrm{L}}$ and $\mathrm{S}_{\mathrm{h}}$.

First study on recirculation zone was conducted by [1] but there was no flow measurement. Flow measurement in groyne field was firstly tried by [2]. The study was conducted on two types of groyne having different length and measured the flow as separating the flow field to -1 $\leq \mathrm{x} / \mathrm{b} \leq 6$ and $0 \leq \mathrm{y} / \mathrm{b} \leq 3 ; \mathrm{x}$ is channel length, $\mathrm{y}$ is horizontal distance from bank and $b$ is groyne length. However, they did not analyze the characteristic of recircula- tion zone on groyne length and permeability only with two types of groyne. [3] presented the characteristic of local flow around groyne through numerical calculation on recirculation zone. But it just applied to impermeable groyne and did not specifically deal with a groyne effect on flow separation and thalweg.

The purpose of the study is to understand the flow characteristics depending on size of recirculation zone and variation of velocity distribution by groyne types as focusing groyne installation on role of aquatic habitats and provide the fundamental data which were used to estimate the aquatic habitats of groyne fields.

\section{Experiments}

As shown in Figure 1, flow measurement test for single groyne was conducted in straight flume having $2.0 \mathrm{~m}$ width, $0.8 \mathrm{~m}$ height and $40 \mathrm{~m}$ length. Experiment conditions on permeable and impermeable groyne were represented in Table 1. The four types of impermeable groyne length is $0.2 \mathrm{~m}, 0.3 \mathrm{~m}, 0.4 \mathrm{~m}$ and $0.5 \mathrm{~m}$ and the rate of groyne length to flume width, $1 / \mathrm{B}$ is $0.1,0.15,0.2$ and 0.25 respectively.

Permeable groyne having $0.3 \mathrm{~m}$ length was set up the permeability, $\mathrm{P}$ to $20 \%$ and $40 \%$ respectively. $\mathrm{P}$ is the ratio of flow capacity area to total groyne area as shown in Figure 2 and it built the round shaped pillars, which 


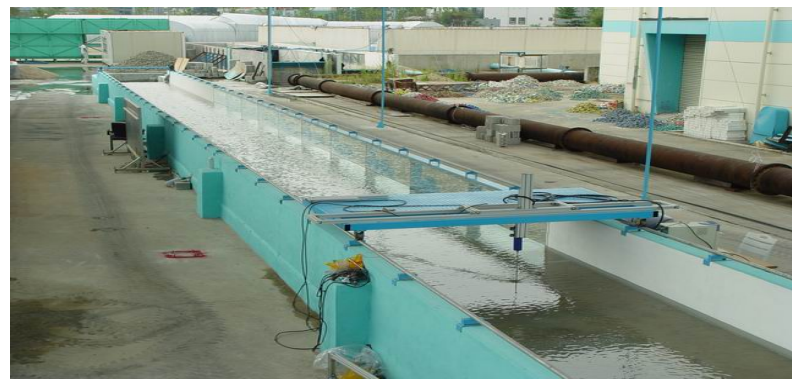

Figure 1. Experimental channel.

Table 1. Experimental conditions for permeable and impermeable groyne.

\begin{tabular}{|c|c|c|c|c|}
\hline \multirow{2}{*}{ experimental conditions } & \multirow{2}{*}{$\begin{array}{c}\text { SF-series } \\
\begin{array}{c}\text { length of } \\
\text { groyne }\end{array}\end{array}$} & \multicolumn{3}{|c|}{ permeability () \% } \\
\hline & & 0 & 20 & 40 \\
\hline \multirow{4}{*}{$\begin{array}{c}\mathrm{Q}=0.075 / 0.090 / 0.120 \mathrm{CMS} \\
\mathrm{H}=0.15 \mathrm{~m} \\
\mathrm{U}=0.25 / 0.30 / 0.40 \mathrm{~m} / \mathrm{s}\end{array}$} & 0.10 & SF10P00 & SF10P20 & SF10P40 \\
\hline & 0.15 & SF $15 P 00$ & SF15P20 & SF15P40 \\
\hline & 0.20 & SF20P00 & SF20P20 & SF20P40 \\
\hline & 0.25 & $\mathrm{SF} 25 \mathrm{P} 00$ & $\mathrm{SF} 25 \mathrm{P} 20$ & SF25P40 \\
\hline
\end{tabular}

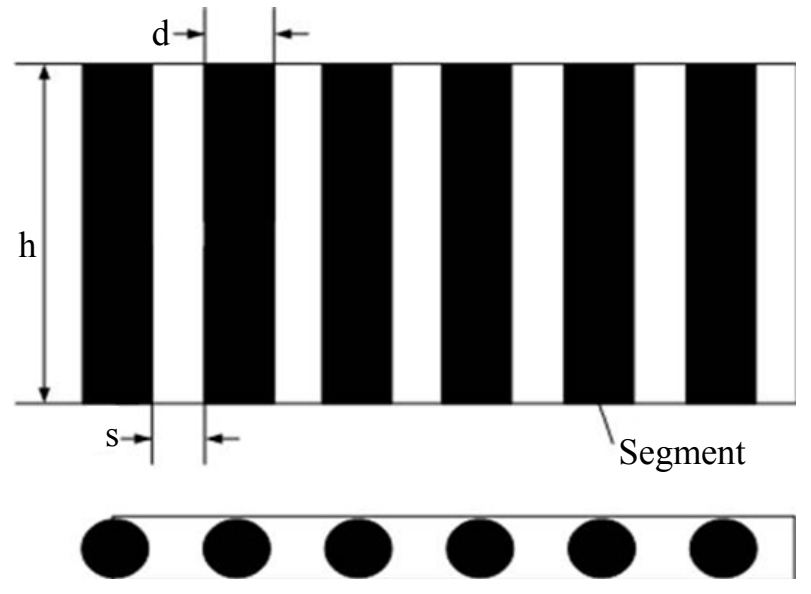

Figure 2. Sketch of permeable groyne.

have constant space to control permeability. Flow condition for experiment is three and mean velocity for each flow condition having constant water depth, $0.15 \mathrm{~m}$ is $0.25,0.3$ and $0.4 \mathrm{~m} / \mathrm{s}$. Froude number is $0.21,0.25$ and 0.33 respectively.

As shown in Figure 3, inclined crest groyne has 0.15 $\mathrm{m}$ height (hg), $0.6 \mathrm{~m}$ length (l) and $15^{\circ}$ inclination angle and was built to bank, having inclination angle of $45^{\circ}$. The two types of inclined crest groyne were used as shown in Figures 3(a) and (b); board type and side sloping type. To understand the flow characteristic to water level variation, the various experimental conditions were conducted as changing the ratio of water depth to groyne height, d/hg range from 0.6 to 1.19 (refer to Table 2).
Table 2. Experimental conditions for inclined crest groyne.

\begin{tabular}{cccccccc}
\hline \multirow{5}{*}{$\begin{array}{c}\text { depth } \\
\mathrm{d}(\mathrm{m})\end{array}$} & $\begin{array}{c}\text { groyne } \\
\text { length } \\
\mathrm{L}^{\prime}(\mathrm{m})\end{array}$ & $\begin{array}{c}\text { depth/groyne } \\
\text { height }\end{array}$ & $\begin{array}{c}\text { discharge } \\
\mathrm{Q}(\mathrm{cm} / \mathrm{s})\end{array}$ & $\begin{array}{c}\text { approach } \\
\text { velocity } \\
\mathrm{V}(\mathrm{m} / \mathrm{s})\end{array}$ & $\mathrm{Fr}$ \\
\hline 0.090 & 0.400 & 0.60 & 0.050 & 0.352 & 0.37 \\
& 0.110 & 0.351 & 0.73 & 0.050 & 0.281 & 0.27 \\
side sloping & 0.117 & 0.334 & 0.78 & 0.083 & 0.434 & 0.41 \\
type & 0.118 & 0.332 & 0.79 & 0.095 & 0.492 & 0.46 \\
& 0.130 & 0.304 & 0.87 & 0.110 & 0.510 & 0.45 \\
& 0.135 & 0.292 & 0.90 & 0.126 & 0.559 & 0.49 \\
& 0.142 & 0.276 & 0.95 & 0.130 & 0.544 & 0.46 \\
& 0.146 & 0.266 & 0.97 & 0.140 & 0.567 & 0.47 \\
& 0.090 & 0.400 & 0.60 & 0.05 & 0.373 & 0.40 \\
& 0.120 & 0.327 & 0.80 & 0.075 & 0.410 & 0.38 \\
& 0.134 & 0.294 & 0.89 & 0.093 & 0.409 & 0.36 \\
& 0.141 & 0.278 & 0.94 & 0.101 & 0.421 & 0.36 \\
& 0.150 & 0.257 & 1.00 & 0.108 & 0.424 & 0.35 \\
& 0.179 & 0.193 & 1.19 & 0.142 & 0.456 & 0.34 \\
\hline
\end{tabular}

\section{Flow Characteristic in Recirculation Zone of Permeable and Impermeable Groyne}

Surface flow around groyne field on each experimental condition was measured by LSPIV and the result of measurement was shown in Figure 4. To grasp the size of recirculation zone for each experiment, the width and length of recirculation zone from installation wall of groyne were measured and analyzed.

Figure 5 represents the change of recirculation field of groyne, having 0.15 of $1 / \mathrm{B}$ depending on flow condition. Vertical axis was normalized as dividing horizontal distance (y) from installation wall to flume width (B) and horizontal axis as dividing distance from groyne installation point to downstream area to groyne length (1). The length of recirculation zone, $S_{L}$ for impermeable groyne represented in 12 times of groyne length. In the case of permeable groyne, as the increase of permeability and $\mathrm{S}_{\mathrm{L}}$ was decreased [4].

Width of recirculation field increases as groyne length increases, as shown in Figure 6 and in the range of 0.10 0.25 , width of recirculation field reaches up to $50 \%$ of flume width. In Figure 7, the width is in inverse proportion to permeability. Thus as permeability increases, the width decreases. Variation of $S_{h}$ to Froude number is insignificant and the result is well agreed with experiment result for permeable groyne by [5]. In case of impermeable groyne, the ratio of $S_{h}$ to groyne length, $S_{h} / 1$ is from 1.9 to 2.4 and width of recirculation field is approximately two times of groyne length. In case of permeable groney, the range of $\mathrm{S}_{\mathrm{h}} / 1$ having $20 \%$ and $40 \%$ of permeability is $1.6-1.8$ and $1.3-1.5$ respectively. 

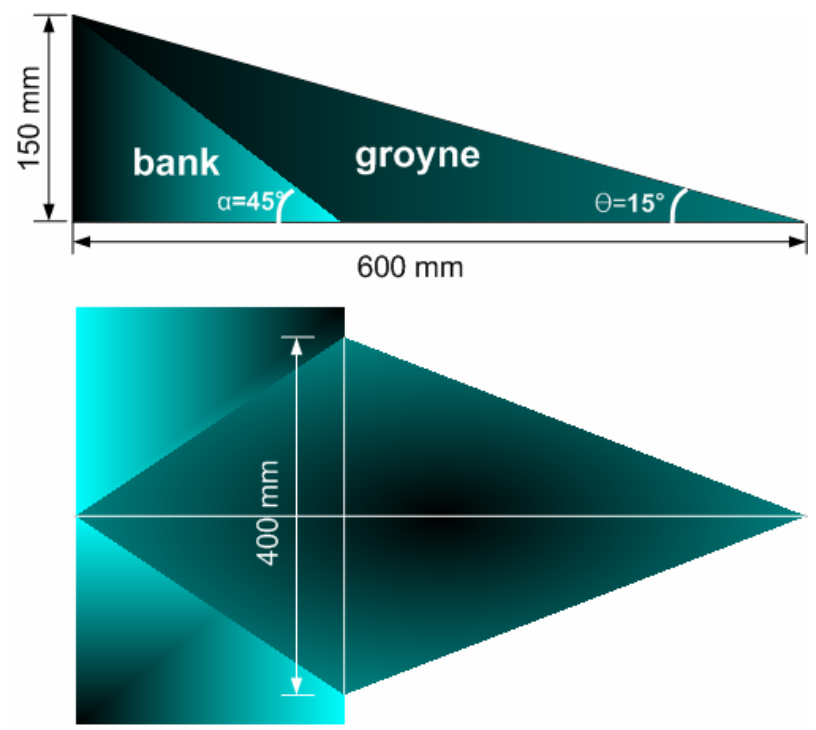

(a)

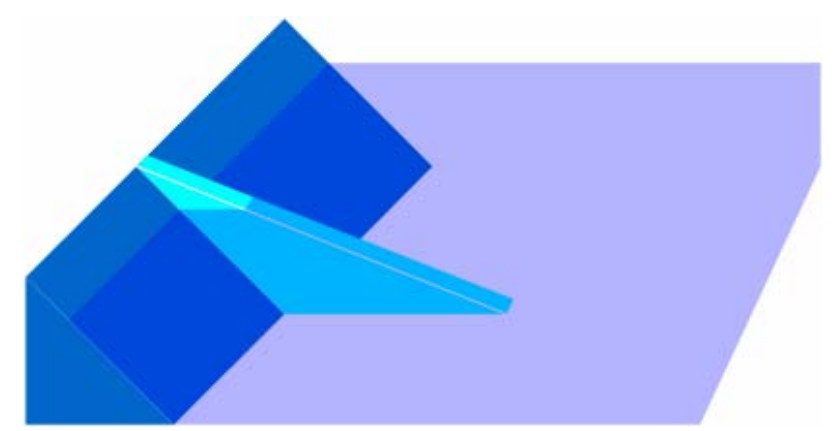

(b)

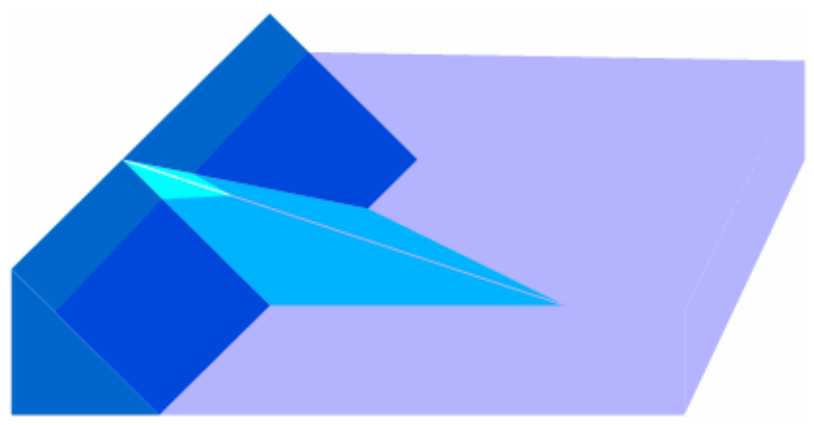

(c)

Figure 3. Inclined crest groyne. (a) Dimension of inclined crest groyne; (b) Board type; (c) Side sloping type.

Protruded structure such as groyne decreases the flow velocity around bank and riverside or retards the flow as occurring back current. On the other hand, it might increase the flow of main channel as the flow capacity decreases. Figure 8 represents velocity distribution in crossing direction on groyne length and permeability.

$\mathrm{X}$ axis is normalized as dividing the velocity of flow direction to mean velocity and $\mathrm{y}$ axis normalized as dividing the distance from side wall to flume width. Side line was illustrated as measuring groyne length up to 12 times. As shown in Figures 8(a) and (b), in case of impermeable groyne, flow velocity in mainstream field increases up to $1.3-2.0$ time of mean velocity when 1/B increases from 0.10 to 0.25 .

In case of permeable groyne, increase of flow velocity in main stream field decreases as permeability increases due to effect of permeation. The flow increase for $40 \%$ of permeability is less than $10 \%$ of maximum velocity of mainstream and the groyne having $20 \%$ permeability is less than $30 \%$ of maximum velocity of mainstream. From experiment result, it revealed the flow variations on flow direction. In Figure 8 sideline having maximum velocity to opposite flow direction was situated in point where is far 5 - 6 times of groyne length from groyne. This result was constant regardless of groyne length, permeability, groyne type and flow condition.

\section{Flow Characteristic of Inclined Crest Groyne in Recirculation Field}

It is important to understand the characteristic of inclined crest groyne in recirculation field because the characteristic of inclined crest groyne is different from general groyne. In this study, it analyzed width $\left(\mathrm{S}_{\mathrm{h}}\right)$, length $\left(\mathrm{S}_{\mathrm{L}}\right)$ of recirculation field and flow distribution in recirculation field to understand the characteristic in recirculation field.

The width of recirculation field decreases as the increase of the water level and the width of board type was larger than inclined crest groyne, which was about 30\% $100 \%$ as shown in Figure 9. As applying conversion permeability based on permeability of general groyne, $\mathrm{P}_{\text {tr }}$, result of the study is well agreed with previous research result by [4] as shown in Figure 10. In Figures 11 and 12 , length of recirculation field decreases as water level increases and the length of board type is longer than inclined crest groyne, which is about from $45 \%$ up to $110 \%$. Recirculation length variation for impermeable groyne was similar to the permeable groyne as applying conversion permeability, $\mathrm{P}_{\text {tr }}$. Maximum back current is occurred between 0.4 and 0.7 times of SL as shown in Figure 13. Magnitude of flow velocity for inclined type is 0.3 time of mean velocity and board type is 0.45 time of mean velocity.

\section{Results}

Fish swimming speeds are classified to sustained swim speed, prolonged swim speed and burst swim speed. Sustained swim speed is the speed that fish can maintain for long period over 200 minutes without muscular fatigue. Prolonged speed is the speed that fish can maintain for 20 seconds to 200 minutes. Burst speed is the highest speed attainable by fish and for only short periods of time below 20 seconds [6]. Critical speed in habitat is 

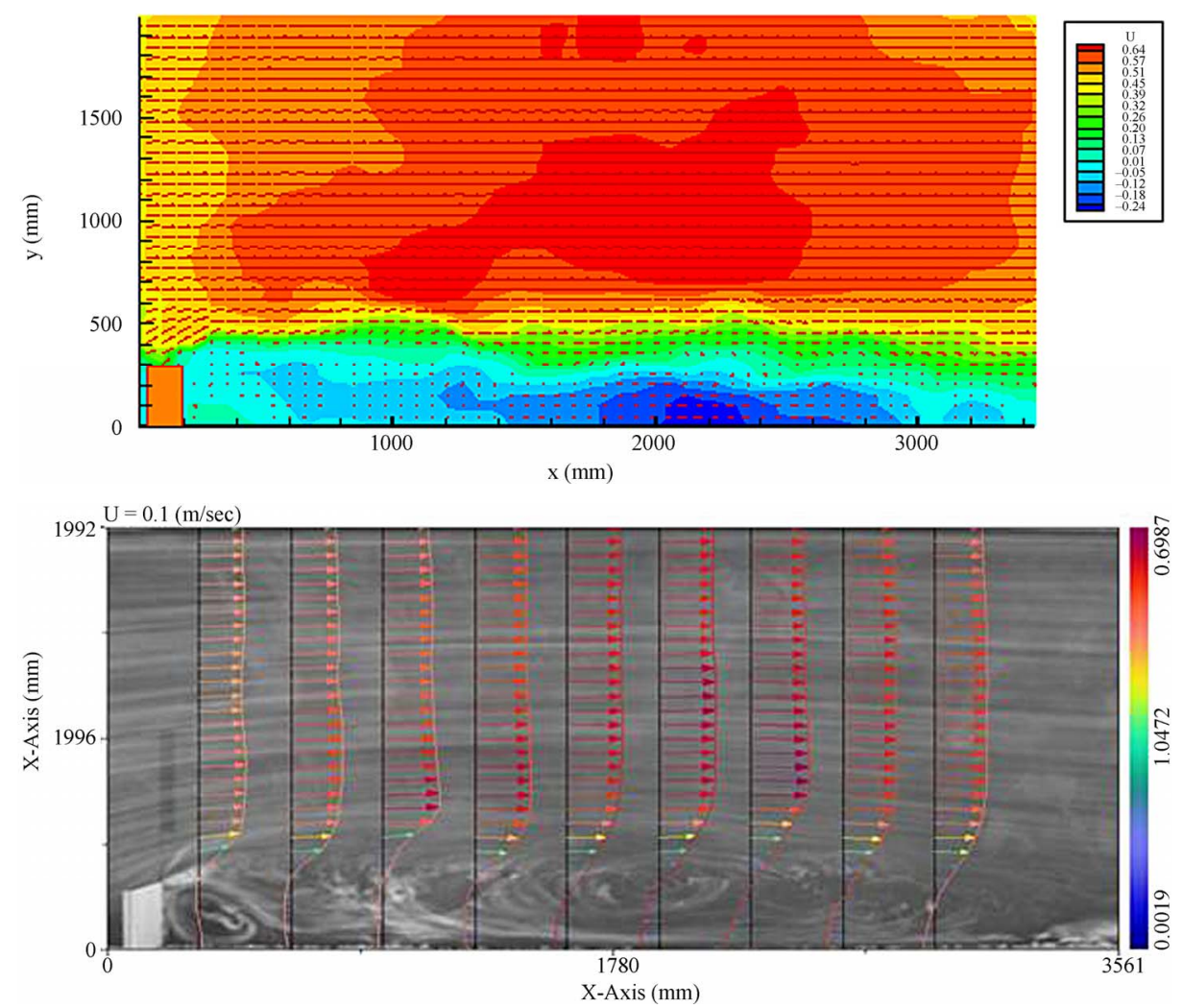

Figure 4. Flow fields obtained with LSPIV.

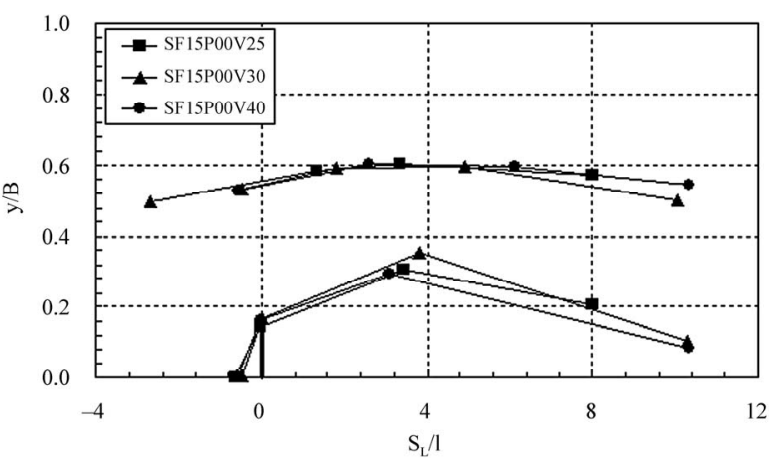

(a)

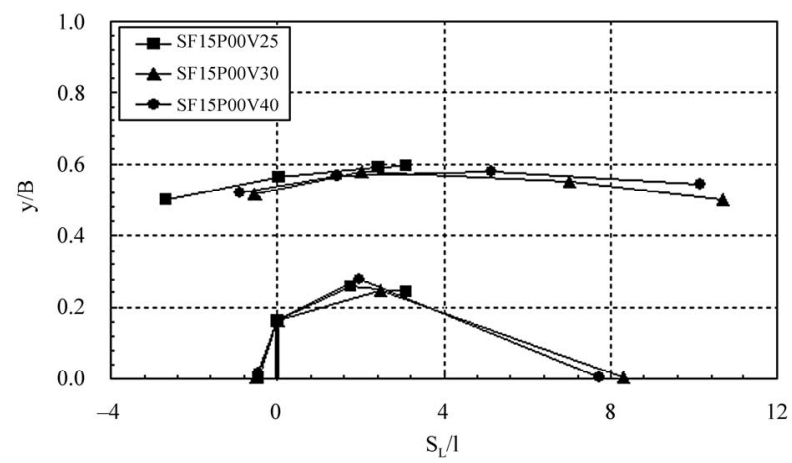

(b)

Figure 5. Variation of thalweg alignment and separation area. (a) Impermeable groyne; (b) Permeable groyne ( $\mathrm{P}=$ $20 \%)$. sustained or prolonged speed, which is the maximum velocity that can be maintained by a fish for a specific period of time [7]. Table 3 shows critical velocity for aquatic habitats of major freshwater fish in Korea. Range of habitable critical velocity of spawn, juvenile and adult fish is $5-70 \mathrm{~cm} / \mathrm{s}$.

Effect of decreasing velocity in goryne fields varied with type of groyne, shown in Figure 14. The results can provide the fundamental data to evaluate aquatic habitats function of goryne in flood flow. In Figure 14, contour represents the rate of velocity decreasing which is the ratio of velocity, $\mathrm{V}$ is approach velocity, $\mathrm{V}_{\text {app }}$ and range of $\mathrm{V} / \mathrm{V}_{\text {app }}$ with groyne types show $0-0.5$. From the results for effect of decreasing velocity by groyne, the groyne fields can be aquatic habitats of most major flesh water fish in Korea. However, in case of $40 \%$ impermeable groyne, area for habitats of fish was limited to near downstream of groyne and impermeable groyne must be designed with proper permeability to aquatic habitats.

\section{Conclusions}

This study was about aquatic habitats of goryne, hydraulic characteristics around groyne were analysed. Flow fields of groyne were measured by LSPIV. Flow variation on groyne type and flow conditions was analysed. The study on groyne for aquatic habitats function was focused on dimension and rate of velocity decreasing in 


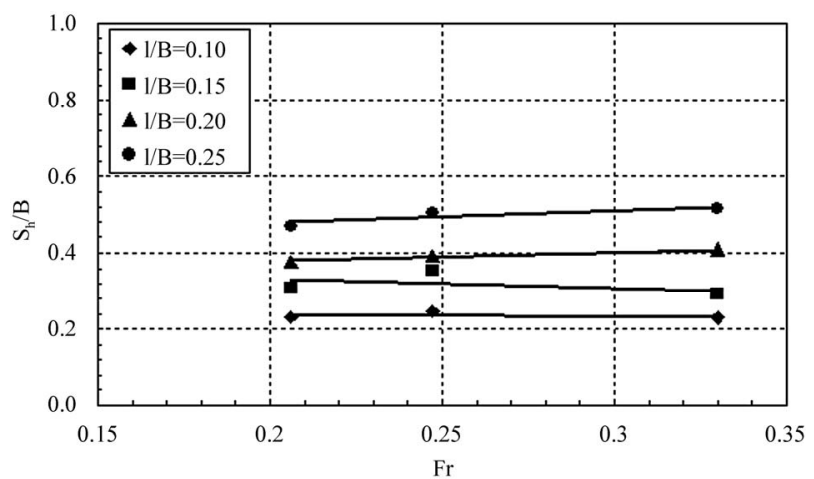

Figure 6. Relationship of $S_{h}$ and Fr.

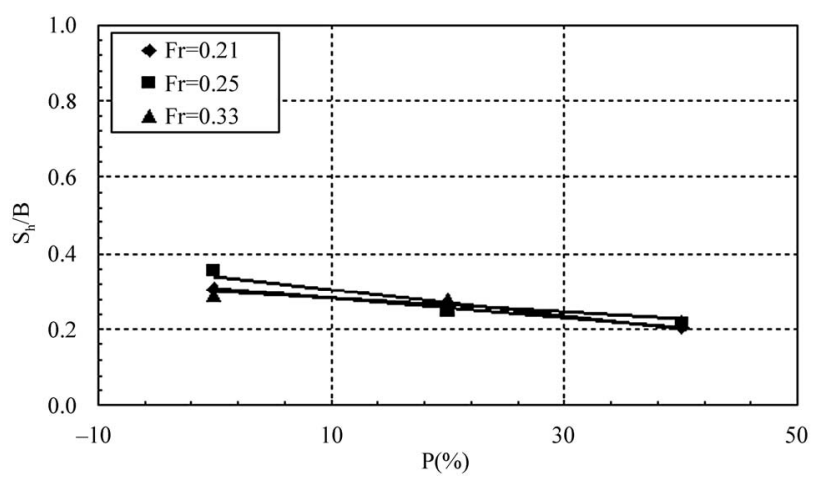

Figure 7. Relationship of $S_{h}$ and $P$.

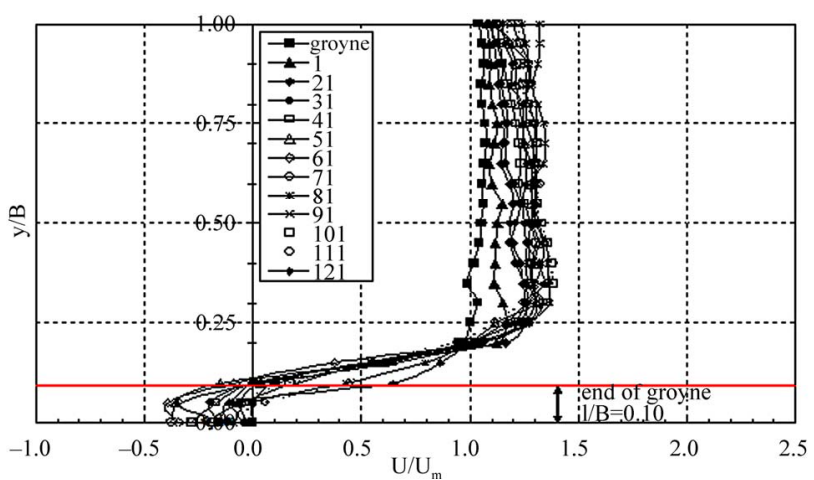

(a)

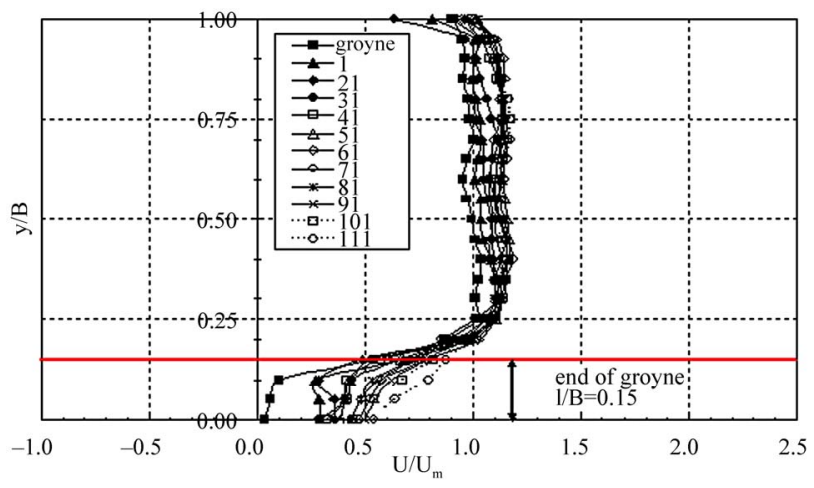

(b)

Figure 8. Velocity distribution of the fields of groyne. (a) Impermeable, $1 / B=0.15$; (b) $P=40 \%, 1 / B=0.15$.

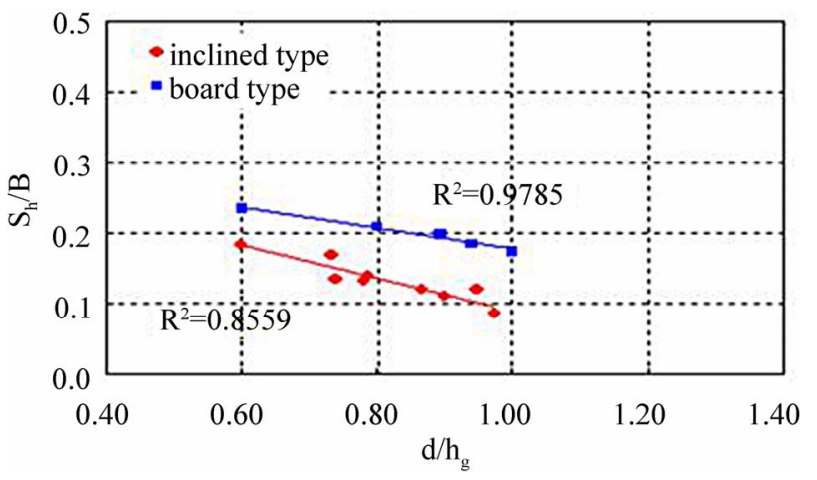

Figure 9. Variation of $S_{h}$ with $d / h_{g}$.

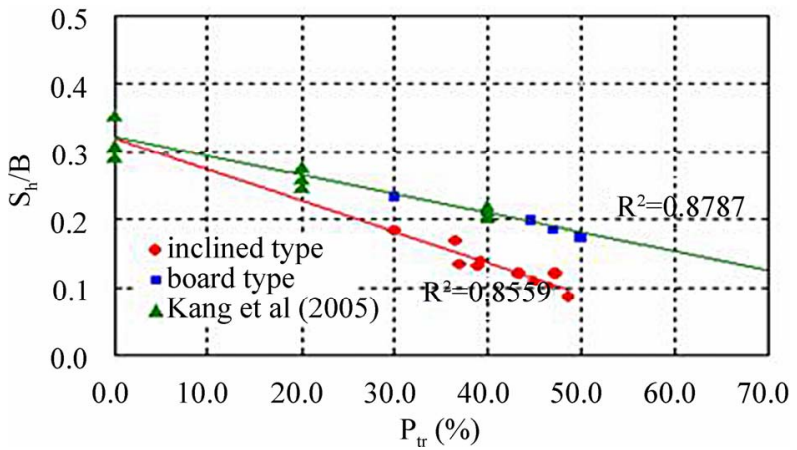

Figure 10. Variation of $S_{h}$ with $P_{t r}$.

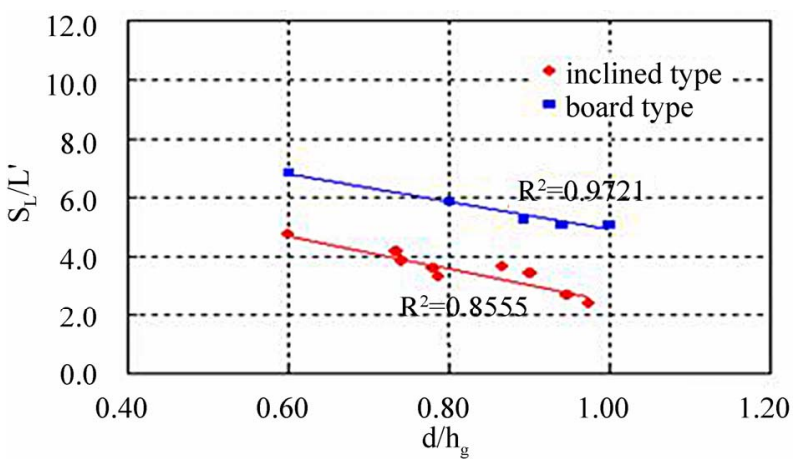

Figure 11. Variation of $S_{L}$ with $d / h_{g}$.

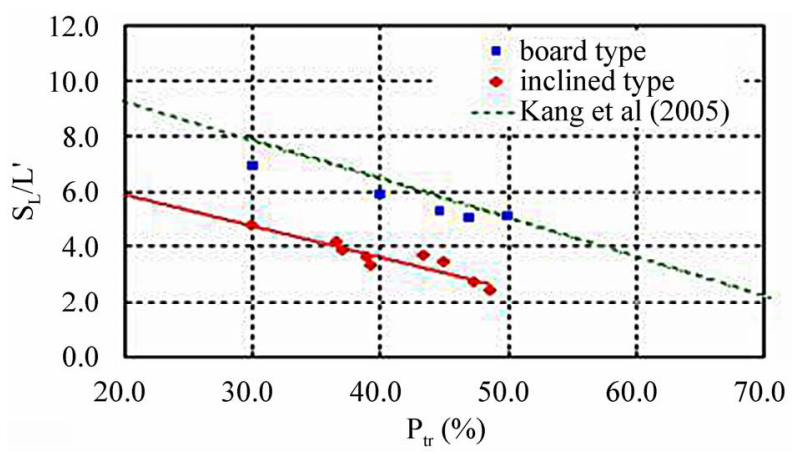

Figure 12. Variation of $S_{L}$ with $P_{t r}$.

recirculation area. Therefore, in order to understand flow around groyne, height $\left(S_{h}\right)$, length $\left(S_{L}\right)$ and variation of 


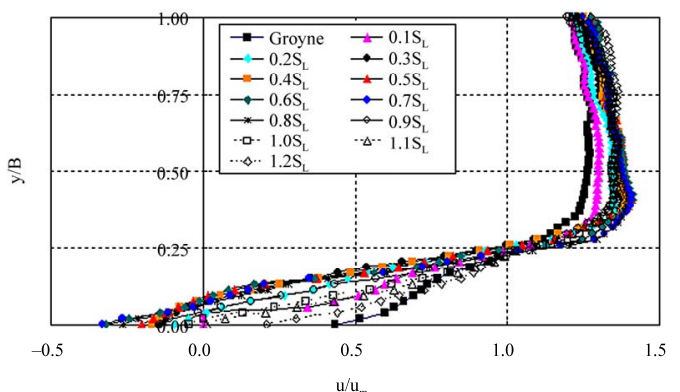

(a)

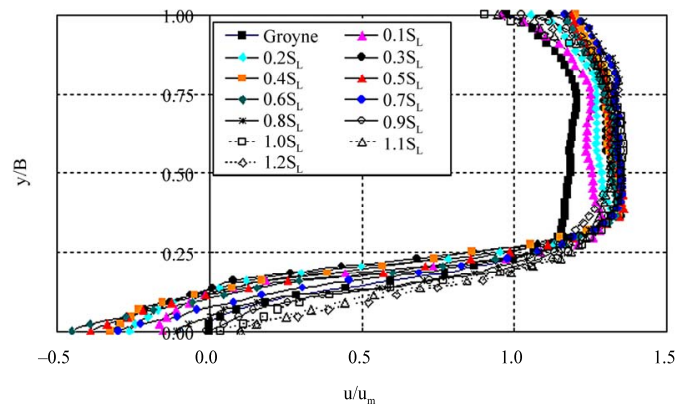

(b)

Figure 13. Velocity distribution of recirculation zone. (a) Side sloping type; (b) Board type.

Table 3. Critical velocity of aquatic habitat for major freshwater fish in Korea.

\begin{tabular}{|c|c|c|c|c|c|}
\hline \multirow{2}{*}{ Species } & \multirow{2}{*}{$\begin{array}{l}\text { Scientific } \\
\text { name }\end{array}$} & \multirow{2}{*}{$\begin{array}{l}\text { Length } \\
\text { (cm) }\end{array}$} & \multicolumn{3}{|c|}{ Critical velocity $(\mathrm{cm} / \mathrm{s})$} \\
\hline & & & Spawn & Juvenile & Adult \\
\hline Carp & $\begin{array}{l}\text { Cyprinus } \\
\text { carpio }\end{array}$ & 120 & $5-10$ & $10-20$ & $20-30$ \\
\hline Crusian carp & $\begin{array}{l}\text { Carassius } \\
\text { carassius }\end{array}$ & $20-43$ & $5-10$ & $10-20$ & $20-30$ \\
\hline Long-nosed barbell & $\begin{array}{l}\text { Hemibarbus } \\
\text { longirostris }\end{array}$ & $15-18$ & $5-10$ & $20-30$ & $30-70$ \\
\hline Minnow & $\begin{array}{c}\text { Zacco } \\
\text { platypus }\end{array}$ & $8-12$ & 10 & $10-20$ & $30-60$ \\
\hline 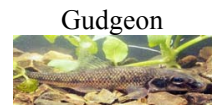 & $\begin{array}{l}\text { Pseudogobio } \\
\text { esocinus }\end{array}$ & 15 & $5-10$ & $10-20$ & $30-50$ \\
\hline Skin carp & $\begin{array}{c}\text { Hemibarbus } \\
\text { labeo }\end{array}$ & $10-50$ & $10-20$ & $20-30$ & $30-50$ \\
\hline $\begin{array}{c}\text { Korean } \\
\text { piscivorous chub }\end{array}$ & $\begin{array}{c}\text { Opsariichthys } \\
\text { bidens }\end{array}$ & 30 & $10-20$ & $20-30$ & $30-50$ \\
\hline Kawasappa & $\begin{array}{l}\text { Hemiculter } \\
\text { eigenmanni }\end{array}$ & $15-20$ & $5-10$ & $10-20$ & $20-30$ \\
\hline False dace & $\begin{array}{l}\text { Pseudoras- } \\
\text { bora parva }\end{array}$ & $6-9$ & $5-10$ & $10-20$ & $20-30$ \\
\hline
\end{tabular}

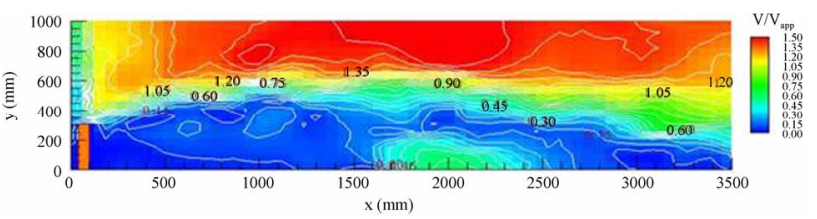

(a)

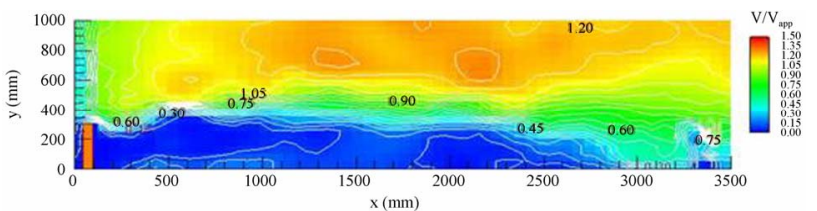

(b)

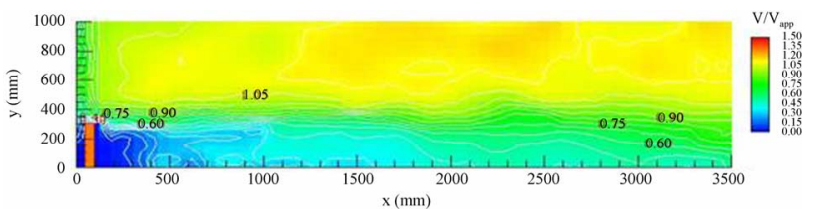

(c)

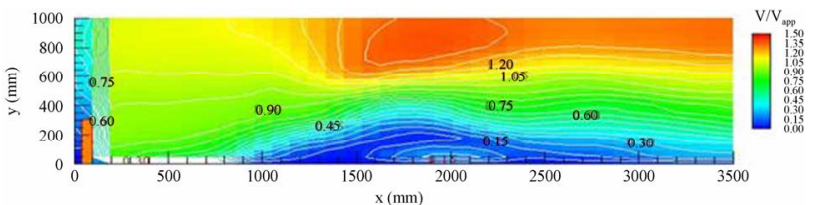

(d)

Figure 14. Contour of decreasing velocity rate in groyne fields. (a) Impermeable groyne (SF15P20); (b) $20 \%$ permeable groyne (SF14P20); (c) 40\% permeable groyne (SF14P40); (d) Inclined crest groyne.

velocity distribution of recirculation area were investigated.

The velocity distributions varied with groyne types and the rate of velocity decreasing in groyne fields, $\mathrm{V} / \mathrm{V}_{\text {app }}$ were measured 0 to 0.5 . The results can be fundamental data which were used to evaluate the aquatic habitats function of groyne. Also, if the research on ecological characteristics of fish is added, it can be important data for design of groyne which has function of aquatic habitats.

\section{Acknowledgements}

This study was supported by the Internal Research Project of "River Structure Design Techniques for Harmonizing Nature with the Human" in KICT.

\section{REFERENCES}

[1] J. R. Francis, A. Pattanick and S. Wearne, "Observations of Flow Patterns around Some Simplified Groyne Structures in Channels," Technical Note No. 8, Proceedings of Institution of Civil Engineers, London, December 1968, pp. 829-846.

[2] N. Rajaratnam and B. Nwachukwu, "Flow Near Groyne- 
Dike Structures," Journal of Hydraulic Division, Vol. 109, No. HY3, 1983, pp. 463-480.

doi:10.1061/(ASCE)0733-9429(1983)109:3(463)

[3] T. Tingsanchali and S. Maheswaran, "2D Depth-Averaged Flow Computation near Groyne," Journal of Hydraulic Engineering, Vol. 116, No. 1, 1990, pp. 71-86. doi:10.1061/(ASCE)0733-9429(1990)116:1(71)

[4] J. G. Kang, H. K. Yeo and S. J. Kim, "An Experimental Study on Tip Velocity and Downstream Recirculation Zone of Single Groyne Conditions," Journal of Korea Water Resources Association, Vol. 38, No. 2, 2005, pp. 143153. doi:10.3741/JKWRA.2005.38.2.143

[5] R. Ettema and M. Muste, "Scale Effects in Flume Ex- periments on Flow around a Spur Dike in Flatbed Channel," Journal of Hydraulic Engineering, Vol. 130, No. 7, 2004, pp. 635-646. doi:10.1061/(ASCE)0733-9429(2004)130:7(635)

[6] F. W. H. Beamish, "Swimming Capacity," Fish Physiology, Vol. 7, 1978, pp. 101-187. doi:10.1016/S1546-5098(08)60164-8

[7] J. R. Brett, "The Respiratory Metabolism and Swimming Performance of Young Sockeye Salmon," Journal of Fisheries Research Board of Canada, Vol. 21, No. 5, 1964, pp. 1183-1226. doi:10.1139/f64-103 